\title{
ANALISIS PREVALENSI DAN INTENSITAS EKTOPARASIT IKAN KERAPU TIKUS (Cromileptes altevalis) DI KERAMBA JARING APUNG PERAIRAN TELUK KAYELI KABUPATEN BURU
}

\author{
Samsia Umasugi, Asdar Burhanuddin \\ Staf Pengajar Prodi Budidaya Perairan-Universitas Iqra Buru, e-mail: -
}

\begin{abstract}
ABSTRAK
Penelitian ini bertujuan untuk mengetahui jenis-jenis parasit, tingkat serangan, prevalensi dan intensitas Ektoparasit, juga bagaimana pengaruh hubungan kualitas air terhadap serangan parasit pada ikan Kerapu Tikus (Cromileptes altevalis) dalam wadah budidaya (KJA . Metode pengambilan sampel adalah ikan Kerapu Tikus (Cromileptes altevalis) diambil pada keramba jaring apung (KJA) di Perairan Teluk Kayeli secara acak sebanyak 20 ekor dengan ukuran yang bervariasi dan selanjutnya sampel ikan diperiksa di Balai Budidaya Laut Ambon, lalu diamati organ tubuh ikan yang meliputi sisik, sirip, insang dan mata, hal ini untuk mempermudah identifikasi menggunakan proses metode staining carmine borax. Berdasarkan hasil yang diperoleh maka ektoparasit yang ditemukan menginfeksi ikan Kerapu Tikus (Cromileptes altevalis) selama penelitian berjumlah 31 individu yang terdiri dari satu Filum yakni Cliopora yakni Trichodina sp dan Cryptocaryon sp, yang merupakan ektoparasit terbanyak yang ditemukan yakni 28 individu dengan tingkat prevalensi $70 \%$ dengan nilai intensitas 2 ind/ekor serta nilai kelimpahannya 0,4. Dari hasil pemeriksaan terhadap organ tubuh ikan Kerapu Tikus (Cromileptes altevalis) ternyata organ insang merupakan organ tubuh yang paling banyak terinfeksi ektoparasit yakni 13 individu dibandingkan dengan ketiga organ lainnya.
\end{abstract}

Kata Kunci: Prevalensi, Intensitas, Ektoparasit, Kerapu Tikus (Cromileptes altevalis

\section{PENDAHULUAN}

1.1. Latar Belakang

Indonesia sebagai negara kepulauan mempunyai sumberdaya laut yang melimpah. Dengan panjang garis pantai $81.000 \mathrm{~km}$, Indonesia mempunyai potensi yang sangat besar dalam pengembangan sektor perikanan. Selain sebagai penyokong kebutuhan protein hewani, juga membuka lapangan kerja, menambah pendapatan masyarakat sebagai sumber devisa negara bahkan saat ini komoditas ekspor (Nontji, 1987). Sedangkan Anonim (1994) menyatakan bahwa pemanfaatan perairan laut dan pantai serta sumberdayanya untuk kegiatan budidaya ikan telah lama dikembangkan dan terus ditingkatkan. Salah satu pemanfaatan budidaya perairan laut yang cukup menjanjikan prospek yang bagus adalah budidaya ikan Kerapu Tikus (Cromileptes altevalis).

Ikan Kerapu Tikus (Cromileptes altevalis) memiliki prospek yang sangat cerah untuk dibudidayakan karena merupakan salah satu jenis yang memiliki nilai nilai ekonomis tinggi serta memiliki peluang pasar dalam maupun luar negeri yang sangat baik. Permintaan pasar nasional akan ikan Kerapu Tikus (Cromileptes altevalis) yang cenderung terus meningkat memberikan peluang bagi Indonesia untuk meningkatkan hasil pengangkapannya. Pengangkapan ikan Kerapu Tikus (Cromileptes altevalis) terus-menerus dalam jumlah yang cukup besar tanpa disertai usaha pengembangan 
atau pembudidayaan akan menyebabkan kelebihan tangkap (Over Fishing) dan bahkan kepunahan spesies (Anonim, 1994), untuk itu perlu dilakukan pengembangan budidaya ikan Kerapu baik secara kuantitas maupun kualitas.

Faktor yang sangat penting dalam menunjang kelangsungan hidup ikan Kerapu Tikus (Cromileptes altevalis) yang dibudidayakan adalah lingkungan perairan yang tertata dengan baik. Namun lingkungan yang tertata dengan baik, nampaknya belum cukup untuk menjamin keberhasilan budidaya perairan. Salah satu faktor kegagalan budidaya perairan yang sering dihadapi adalah kematian yang disebabkan oleh penyakit misalnya karena serangan parasit. Parasit yang masuk/menginfeksi dapat melalui berbagai media seperti air, manusia atau juga lewat peralatan budidaya (Purnomowati dkk, 2002).

Mengingat efek parasit terhadap ikan (sebagai inang) berupa kerusakan mekanik seperti yang dikemukakan Hong (1973) dalam Rumagia, S (2001) bahwa dapat menurunkan stok ikan, menurunkan mutu ikan akibat cacat serta dapat pula membahayakan kesehatan manusia, maka perlu kiranya dilakukan identifikasi parasit serta pengendalian atau penanganan parasit itu sendiri agar tidak membahayakan dan merugikan organisme budidaya.

1.2. Tujuan dan Kegunaan Penelitian

Penelitian ini bertujuan untuk :

1. Mengetahui jenis-jenis parasit, tingkat serangan, prevalensi dan intensitas Ektoparasit terhadap ikan Kerapu Tikus (Cromileptes altevalis) .

2. Untuk mengetahui pengaruh hubungan kualitas air terhadap serangan parasit pada Ikan Kerapu Tikus (Cromileptes altevalis) dalam wadah budidaya.

Sedangkan kegunaannya adalah sebagai bahan informasi bagi masyarakat nelayan, pelaku usaha budidaya ikan, serta pemerintah daerah setempat dalam rangka peningkatan pengelolaan usaha budidaya ikan Kerapu agar terhindar dari serangan parasit guna menunjang produksi budiayanya.

\section{METODE PENELITIAN}

\subsection{Waktu Dan Tempat}

Penelitian ini dilaksanakan pada Bulan Oktober 2013. Pengambilan sampel dilakukan pada lokasi Budidaya Keramba Jaring Apung di Desa Namlea, Kecamatan Namlea, Kabupaten Buru, Propisi Maluku. Pengamatan dan Analisis Prevalensi Ektoparsit pada sampel Ikan Kerapu dilkakukan di Laboratorium Balai Perikanan Budidaya Laut Waiheru - Ambon.

\subsection{Metode Pengambilan Sampel}

Sampel Ikan Kerapu diambil pada wadah budidaya Keramba Jaring Apung (KJA), di perairan teluk kayeli Desa Namlea, sebanyak 10 $\%$ total penebaran yaitu ( 20 ekor ), dari dua petakan KJA ukuran $3 \mathrm{~m} \times 3 \mathrm{~m}$ dengan padat penebaran total 200 Ekor. Sampel diambil secara acak dan dilakukan pengukuran panjang dan berat dan didapatkan berkisar antara $24 \mathrm{~cm}-27$ $\mathrm{cm}$, dan berturut turut beratnya $240 \mathrm{gr}-276 \mathrm{gr}$.

\subsection{Pemeriksaan Sampel}

Pemeriksaan sampel dalam penelitian ini dilakukan dengan memeriksa tubuh bagian dalam dengan cara terlebih dahulu dilakukan pembedahan terhadap sampel ikan. Agar memberikan hasil yang baik, pembedahan dilakukan dengan menggunakan gunting/ pisau yang tajam. Setelah selesai dibedah, baru ikan kemudian diamati pada organ bagian dalamnya. Organ dalam yang yaitu : Sisik, Sirip, Insang dan Mata. Proses pemeriksaan sampel dapat dilihat pada Gambar 1.

\subsection{Analisis Data}

Data Ektoparasit yang ditemukan dari hasil pemeriksaan sampel kemudian di catat agar kemudian dihitung jumlah dan jenis Ektoparsitnya, Dan untuk mengetahui tingkat serangan parasit pada ikan, dapat di Analisis dengan menghitung Prevalensi dan Intensitas menurut (Fernando dkk dalam Rumagia. S, 2001)

$$
\mathrm{P}=\mathrm{N} / \mathrm{n} \times 100 \%
$$

Dimana :

P : Prevalensi

N : Jumlah Sampel yang terinfeksi 
n : Jumlah sampel yang diamati sedangkan intensitas dihitung dengan menggunakan rumus :

$\mathbf{I}=\mathbf{P} / \mathbf{N}$
Dimana :

$I$ = intensitas serangan parasit (ind/ekor)

$\mathbf{P}=$ Jumlah Ektoparasit yang menginfeksi (ind)

$\mathrm{N}=$ Jumlah sampel yang terinfeksi (ekor).

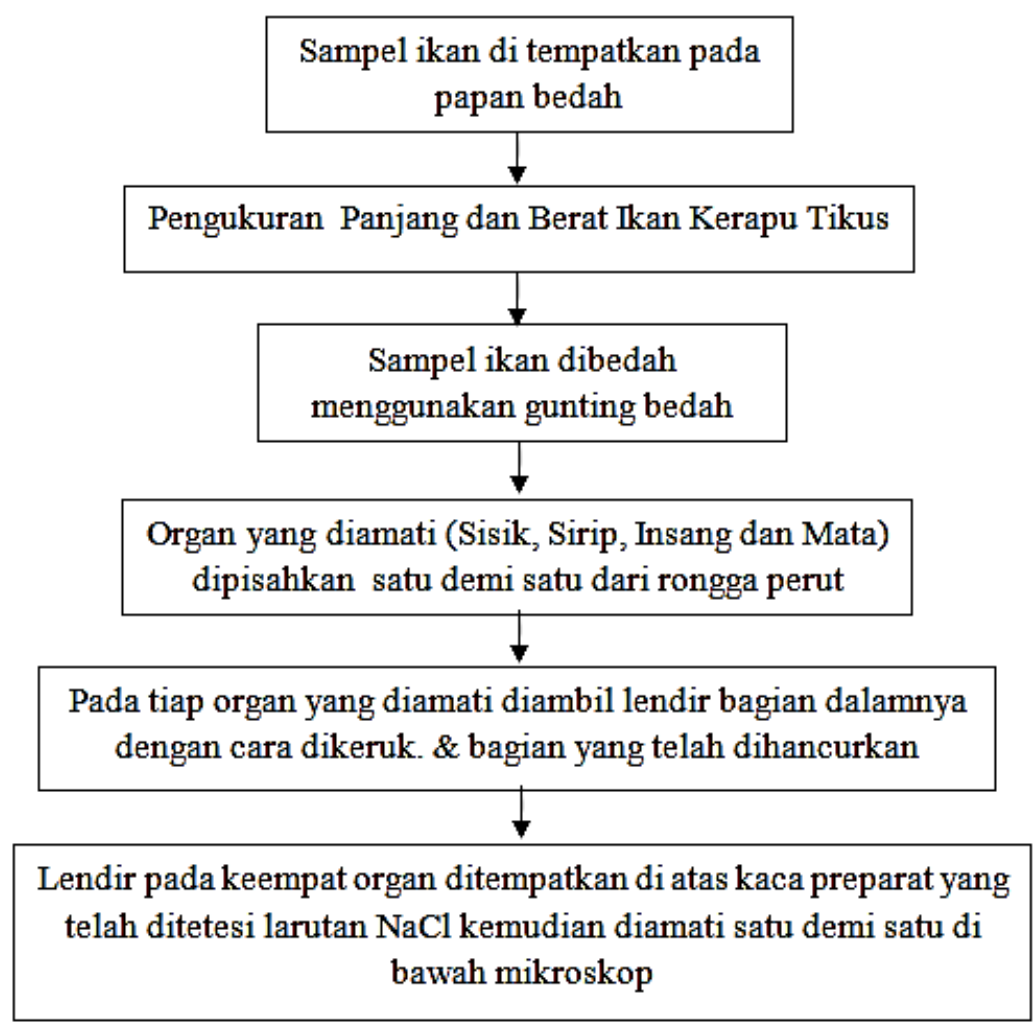

Gambar 1. Proses Pemeriksaan Sampel

\section{HASIL DAN PEMBAHASAN}

\subsection{Kehadiran Ektoparasit}

Berdasarkan hasil pengamatan selama penelitian terhadap ikan Kerapu Tikus (Cromileptes altevalis) maka diperoleh ukuran panjang total ikan Kerapu Tikus berkisar antara $10,00-17,84 \mathrm{~cm}$, sedangkan beratnya berkisar antara 21,98 - 112,27 gr. Hasil pemeriksaan ektoparasit dari 20 ekor inang ternyata ditemukan 14 ekor yang terinfeksi berjumlah 31 individu (Tabel 1).

Tabel 1, terlihat bahwa pada pengambilan III ditemukan jumlah individu ektoparasit tertinggi yaitu 13 individu dengan jumlah intensitas 1,85 ind/ekor. Jumlah ektoparasit terendah ditemukan pada pengambilan I yaitu 6 individu dengan jumlah intensitas ektoparasit 1 ind/ekor.

3.2. Identifikasi Jenis-jenis Ektoparasit dan Indeks Ekologinya

Jenis-jenis ektoparasit yang ditemukam menginfeksi ikan Kerapu Tikus (Cromileptes altevalis) dari 20 ekor individu terbagi dalam satu filum yakni Ciliophora yang terbagi dalam dua family dan dua genus Trichodina $s p$ dan Cryptocaryon sp.

Jenis ektoparasit dan penyebarannya pada organ tubuh bagian luar ikan Kerapu Tikus (Cromileptes altevalis), yang ditemukan selama penelitian dapat dilihat pada Tabel 2 
Tabel 1. Jumlah Kerapu Tikus (Cromileptes altevalis) yang Diamati serta Jumlah Ektoparasit yang Ditemukan Selama Penelitian

\begin{tabular}{cccc}
\hline Waktu Pengambilan & $\begin{array}{c}\text { Jumlah Ikan Kerapu } \\
\text { Tikus (Ekor) }\end{array}$ & $\begin{array}{c}\text { Jumlah Ektoparasit yang } \\
\text { Ditemukan (Ekor) }\end{array}$ & $\begin{array}{c}\text { Rata-rata Ektoparasit } \\
\text { Ind/Ekor }\end{array}$ \\
\hline 08 Oktober 2013 & 6 & 6 & 1,00 \\
16 Oktober 2013 & 7 & 12 & 1,71 \\
23 Oktober 2013 & 7 & 13 & 1,85 \\
\hline Total & 20 & 31 & \\
\hline
\end{tabular}

Tabel 2. Jenis, Jumlah dan Lokasi Penyebaran Ektoparasit yang Ditemukan Menginfeksi ikan Kerapu Tikus (Cromileptes altevalis) Selama Penelitian

\begin{tabular}{llccccc}
\hline \multirow{2}{*}{ No } & \multirow{2}{*}{ Jenis Ektoparasit } & \multicolumn{3}{c}{ Bagian Tubuh yang Diamati } & \multirow{2}{*}{ Jumlah } \\
\cline { 3 - 6 } & & Sisik & Sirip & Insang & Mata & \\
\hline 1 & Trichodina sp & 10 & 6 & 12 & - & 28 \\
2 & Cryptocaryon sp & - & - & 1 & 2 & 3 \\
\hline & Total & 10 & 6 & 13 & 2 & 31 \\
\hline
\end{tabular}

Berdasarkan tabel 2, terlihat bahwa ektoparasit yang ditemukan memiliki jumlah dan penyebaran yang berbeda menurut jenis dan lokasi pengambilan. Secara keseluruhan jenis ektoparasit ditemukan yang paling banyak adalah Trichodina sp, dengan total jumlah parasit yaitu 28 individu dan berikutnya yang paling

Tabel 3. Jumlah Jenis Ektoparasit dan Infeksi Ekologinya

\begin{tabular}{lcccccc}
\hline No & Jenis Ektoparasit & $\begin{array}{c}\text { Junlah Ikan } \\
\text { yang } \\
\text { Terinfeksi } \\
\text { (Ekor) }\end{array}$ & $\begin{array}{c}\text { Jumlah } \\
\text { Parasit } \\
\text { (Ind) }\end{array}$ & $\begin{array}{c}\text { Prevalensi } \\
(\%)\end{array}$ & $\begin{array}{c}\text { Intensitas } \\
\text { Ind/Ekor }\end{array}$ & Kelimpahan \\
\hline 1. & Trichodina $s p$, & 14 & 28 & 70 & 2 & 1,4 \\
2. & Cryptocaryon $s p$ & 3 & 3 & 15 & 1 & 0,15 \\
\hline
\end{tabular}

Berdasarkan Indeks Ekologi (tabel 3) yang dihitung menunjukkan bahwa Trichodina $s p$, mempunyai tingkat prevalensi tertinggi yaitu $70 \%$ dari 20 ekor inang yang diperiksa atau parasit ini menginfeksi inang selama penelitian. Sedangkan tingkat prevalensi terendah ditemukan pada Cryptocaryon $s p$ dengan tingkat prevalensi $15 \%$.

Dari tabel 3 ini juga terlihat bahwa nilai intensitas serangan ektoparasit tertinggi yaitu Trichodina $s p$, dengan nilai sebesar 2 ind/ekor dan nilai intensitas terendah dimiliki oleh Cryptocaryon $s p$ yaitu 1 ind/ekor. Hal ini menunjukkan bahwa tingkat serangan parasit pada ikan Kerapu Tikus (Cromileptes altevalis), parasitnya masih dalam tahap menginfeksi. Hal sedikit adalah Cryptocaryon sp dengan 3 individu. Tabel 2 juga memperlihatkan tingkat infeksi yang berbeda, dimana parasit Trichodina $s p$ lebih banyak ditemukan menempati pada hampir semua bagian tubuh luar ikan Kerapu Tikus (Cromileptes altevalis). ini terbukti bahwa selama penelitian sampel yang dilakukan bahwa belum ada gejala penyakit yang membahayakan. Menurut Soejanto (1972) dalam Rumagia, S (2001) bahwa intensitas 2 - 5 individu/ekor pada tubuh inang belum berbahaya, sedangkan intensitas 10 ind/ekor keatas sudah agi tubuh inang.

3.3. Spesifikasi Jenis Ektoparasit pada Ikan Kerapu Tikus (Cromileptes altevalis)

Dengan menggunakan metode aturan baku prosedur aotupsi penyakit parasit laboratorium (Balai Perikanan Budidaya Laut Waiheru Ambon, 2008) dan Metode Staining (pewarnaan) maka organ tubuh parasit dapat dilihat dengan jelas (Gambar 1 dan 2). Hasil identifikasi yang 
dilakukan dibawah mikroskop dengan berpedoman pada referensi yang ada maka diperoleh jenis-jenis ektoparasit yaitu Trichodina $s p$ dan Cryptocaryon sp.

\section{Trichodina $s p$}

Parasit yang termasuk dalam family Trichonidae ini berbentuk bundar seperti topi, dimana dengan bantuan mikroskop Trichodina $s p$ terlihat berbentuk lingkaran transparan dengan jumlah silia (cilia) yang menempel di sekeliling lingkaran. Pada tubuh bagian bawah terdapat lingkaran pelekat untuk melekatkan dirinya ke tubuh ikan, Gufron, M (2004).

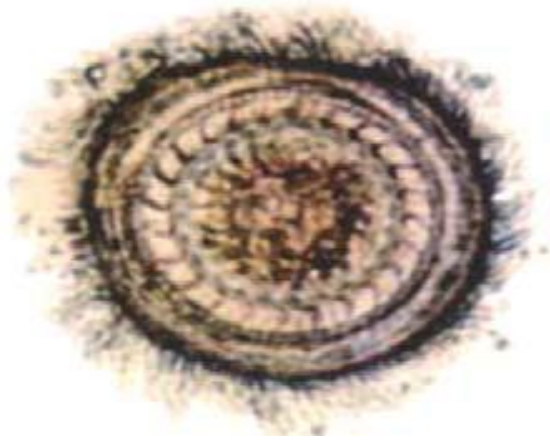

Gambar 1. Parasit Trichodina sp, yang Menginfeksi Ikan Kerapu Tikus (C. altevalis)

Trichodina $s p$ ditemukan menginfeksi hampir seluruh organ tubuh bagian luar ikan yang diamati selama penelitian. Pada permukaan tubuh yang diamati terlihat adanya bintik-bintik putih yang tidak teratur dalam jumlah yang banyak, serta produksi lendir terlihat sangat banyak sehingga kulit kelihatan mengkilap.

Gejala tempat yang ditimbulkan parasit ini adalah ikan berenang lemah ke permukaan, menyendiri (tidak bergerombolan), warna tubuh ikan tidak cerah (kusam) dan sering menggosokgosokkan tubuhnya pada dinding Keramba Jaring Apung (KJA).

Parasit ini menempel pada kulit, sirip, dan insang ikan serta mengakibatkan iritasi di bagian kulit tersebut. Trichodina $s p$ ini dapat menyerang ikan air tawar maupun ikan laut (Anonim, 2002).

\section{Cryptocaryon $s p$}

Cryptocaryon $s p$ adalah ektoparasit pada ikan, biasanya juga disebut white spot karena parasit tersebut menyebabkan bintik-bintik putih pada bagian yang terserang (Anonim, 1985). Penyakit Cryptocaryon $s p$ ini disebabkan oleh protozoa Cryptocaryon $s p$, dimana bagian tubuh yang sering diserang adalah permukaan tubuh, ekor, insang dan juga mata. Gejala ikan yang terserang adalah mata membengkak, insang dan mata ditumbuhi semacam kista sebesar jarum pentul berwarna putih, terjadi pendarahan dan pembusukkan pada bagian sirip dan produksi lendir tubuh meningkat serta nafsu makan hilang (Anonim, 2002).

Parasit ini berbentuk seperti piring yang berbulu getar (cilia), untuk lebih jelasnya dapat dilihat pada gambar 2, Cryptocaryon $s p$ yang belum dewasa dinamakan tingkat trophon. Berbentuk seperti buah per, sedangkan yang dewasa (mature trophon) berbentuk bulat dengan diameter kira-kira 0,3 mm. Organisme ini dapat membentuk kista yang merupakan tingkat akhir pada ikan yang terinfeksi. Dalam daur hidupnya tingkat ini biasanya disebut tomant (Gufron, M, 2004).

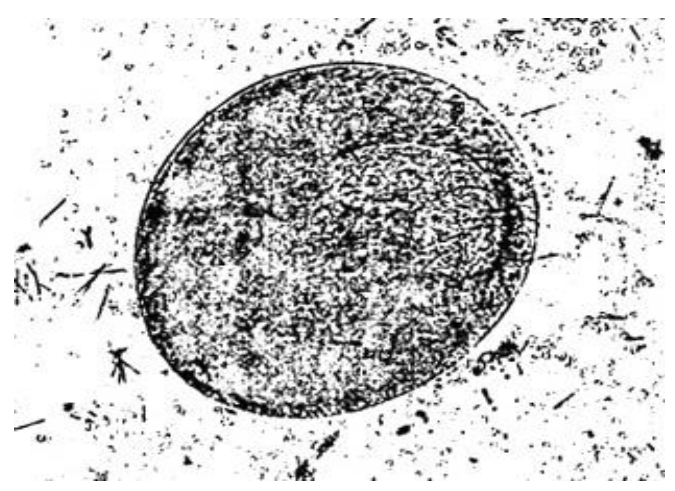

Gambar 2. Jenis parasit Cryptocaryon $s p$

Cryptocaryon $s p$ ditemukan menginfeksi inang bagian sisik dan insang yang ditemukan selama penelitian. Pada permukaan tubuh ikan yang terinfeksi, Cryptocaryon $s p$ terlihat adanya bintik-bintik putih seperti titik, mata membengkak, sisik-sisik lepas serta terjadi pembusukkan pada bagian sirip, akibat dari infeksi sekunder yang dalamnya ikan tampak berenang lemah timbul di permukaan air dan tidak bergerombolan. Hal ini didukung oleh pendapat (Gufron, M, 2004) bahwa ciri dan 
serangan penyakit ini antara lain nafsu makan ikan berkurang, ikan menjadi lesu matanya muram, sisikikan lepas, terdapat bintik-bintik putih pada insang dan kulit permukaan serta produksi lendirnya meningkat. Penyakit ini dapat mengakibatkan kematian massal pada ikan dalam kurun waktu yang singkat.

Cryptocaryon $s p$ ditemukan menginfeksi hampir seluruh organ tubuh bagian luar yang diamati selama penelitian. Pada permukaan tubuh yang diamati terlihat adanya bintik-bintik putih yang tidak teratur, dalam jumlah yang banyak, serta produksi lendir terlihat sangat banyak sehingga kulit kelihatan mengkilap.

\subsection{Tingkat Infeksi Parasit Berdasarkan Ukuran Inang \\ Berdasarkan data ukuran ikan Kerapu} Tikus (Cromileptes altevalis) yang didapatkan selama penelitian untuk ukuran panjang total dan berat yang dikelompokkan menurut selang kelas (tabel 4 dan 5). Ternyata Dari pengelompokan panjang jumlah ikan yang terbesar ditemukan pada selang kelas 15,24 $16,54 \mathrm{~cm}$ yakni 6 ekor, jumlah ikan terkecil ditemukan pada selang kelas 11,32 - 12,61 cm yang masing-masing 2 ekor.

Tabel 4. Jumlah Ektoparasit yang Ditemukan Menginfeksi Ikan Kerapu Tikus (Cromileptes altevalis) Menurut Ukuran Panjang

\begin{tabular}{cccccc}
\hline Panjang (cm) & $\begin{array}{c}\text { Jumlah Ikan } \\
\text { (ekor) }\end{array}$ & $\begin{array}{c}\text { Jumlah Parasit } \\
\text { (ind) }\end{array}$ & $\begin{array}{c}\text { Prevalensi } \\
\text { (\%) }\end{array}$ & $\begin{array}{c}\text { Intensitas } \\
\text { (ind/ekor) }\end{array}$ & Kelimpahan \\
\hline $10,00-11,30$ & 3 & 3 & 15 & 1,0 & 0,15 \\
$11,31-12,61$ & 2 & 8 & 10 & 4,0 & 0,4 \\
$12,62-13,92$ & 2 & 1 & 10 & 0,5 & 0,05 \\
$13,93-15,23$ & 3 & 5 & 15 & 1,66 & 0,25 \\
$15,24-16,54$ & 6 & 5 & 30 & 0,83 & 0,25 \\
$16,55-17,84$ & 4 & 9 & 20 & 2,25 & 0,45 \\
\hline
\end{tabular}

Tabel 5. Jumlah Ektoparasit yang Ditemukan Menginfeksi Ikan Kerapu Tikus (Cromileptes altevalis) Menurut Ukuran Berat

\begin{tabular}{cccccc}
\hline Berat (gr) & $\begin{array}{c}\text { Jumlah Ikan } \\
\text { (ekor) }\end{array}$ & $\begin{array}{c}\text { Jumlah Parasit } \\
\text { (ind) }\end{array}$ & $\begin{array}{c}\text { Prevalensi } \\
\text { (\%) }\end{array}$ & $\begin{array}{c}\text { Intensitas } \\
\text { (ind/ekor) }\end{array}$ & Kelimpahan \\
\hline $21,98-37,02$ & 6 & 11 & 30 & 1,83 & 0,55 \\
$37,03-52,07$ & 3 & 5 & 15 & 1,66 & 0,25 \\
$52,08-67,12$ & 4 & 1 & 20 & 0,25 & 0,05 \\
$67,13-82,17$ & 4 & 5 & 20 & 1,25 & 0,25 \\
$82,18-97,22$ & 1 & 2 & 5 & 2,0 & 0,1 \\
$97,23-112,27$ & 2 & 7 & 10 & 3,5 & 0,35 \\
\hline
\end{tabular}

Berdasarkan data ukuran berat dan panjang yang ditemukan selama penelitian terhadap tingkat serangan parasit ternyata jumlah parasit dengan ukuran ikan tidak menunjukkan suatu hubungan yang mutlak tidak dapat dipastikan bahwa dalam hal ukuran ikan tertentu maka parasit dapat menginfeksi tubuh inang, dengan kata lain ukuran berat dan panjang ikan tidak terlalu berpengaruh terhadap tingkat serangan parasit.

Polyanski (1961) dalam Rumagia, S (2001) menyatakan bahwa tingkat kehadiran parasit berdasarkan umur dapat dibagi atas 3 kondisi, yaitu : a) jumlah parasit bertambah dengan bertambahnya umur inang, b) kehadiran parasit berkurang dengan bertambahnya umur inang, c) kehadiran parasit tidak dipengaruhi oleh umur inang. Namun pada penelitian ini, dimana point a dan $b$ tidak berlaku. Parasit dapat menginfeksi ikan jika ikan tersebut tidak mempunyai daya tahan tubuh yang kuat terhadap serangan parasit, hal ini diakibatkan karena lingkungan perairan yang merupakan lokasi penelitian tidak memadai atau kualitas airnya jelek. 


\subsection{Kualitas Air}

Dilihat dari data kualitas air, ternyata nilai rata-rata kualitas air menunjukkan angka yang berada pada lokasi yang mendukung pertumbuhan organisme budidaya ikan Kerapu Tikus (Cromileptes altevalis), yakni suhu dengan nilai rata-rata $29,89^{\circ} \mathrm{C}$, salinitas $32,19 \mathrm{ppt}$, DO 4,89 ppm dan pH 8,09 (tabel 6). Hal ini sesuai dengan pendapat yang dikemukakan oleh Brotohadikusumo, (1997) dan Anonim (2002), bahwa salinitas yang ideal untuk pembesaran ikan Kerapu Tikus (Cromileptes altevalis) adalah 30 - 33 ppt, suhu $27-2^{\circ} \mathrm{C}$ (Anonim, 2002), Brotohadikusumo (1977) menyatakan bahwa parameter kualitas air khususnya suhu yang baik untuk pembesaran ikan kerapu tikus berkisar antara $28-32^{\circ} \mathrm{C}$ sedangkan $\mathrm{pH}$ dan $\mathrm{DO}$ yang cocok untuk pertumbuhan kerapu tikus adalah $7-8$ untuk $\mathrm{pH}$ dan $>5 \mathrm{ppm}$ untuk parameter DO.

Tabel 6. Data Pengukuran Kualitas Air yang didapatkan pada Lokasi Penelitian

\begin{tabular}{rcccc}
\hline Tanggal & Suhu $\left({ }^{\circ} \mathbf{C}\right)$ & Salinitas (ppt) & DO & pH \\
\hline 08 Oktober 2013 & 29,13 & 32,5 & 5,02 & 8,13 \\
16 Oktober 2013 & 30,30 & 31,9 & 4,76 & 7,16 \\
23 Oktober 2013 & 30,23 & 32,2 & 4,90 & 8,97 \\
\hline Rata-rata & $\mathbf{2 9 , 8 9}$ & $\mathbf{3 2 , 2}$ & $\mathbf{4 , 8 9}$ & $\mathbf{8 , 0 9}$ \\
\hline
\end{tabular}

Adapun parasit yang ditemukan dalam penelitian ini yakni Tricodhina $s p$ dan Cryptocaryon sp. Namun kedua jenis parasit tersebut masih dalam tahap menginfeksi dimana nilai intensitas serangan parasit belum berbahaya bagi organisme yang dibudidayakan, untuk lebih jelasnya mengenai data jumlah parasit, prevalensi, intensitas dan kelimpahan dapat dilihat pada tabel 3,4 dan 5 .

Dengan data pendukung kualitas air ini pula dilihat bahwa jumlah dan jenis parasit yang ditemukan hanya 2 jenis saja, begitupun dengan nilai prevalensi, intensitas serangan parasit dan kelimpahan dimana nilai yang didapatkan relatif kecil, hal ini menunjukkan bahwa nilai rata-rata kualitas air dari ke-empat parameter tersebut berada pada kisaran angka yang optimum bagi kelangsungan hidup organisme yang dibudidayakan (ikan kerapu tikus), sedangkan jumlah parasit, nilai prevalensi, tingkat parasit dan kelimpahan yang ditemukan pada ikan Kerapu Tikus (Cromileptes altevalis) pengaruhnya tidak terlalu berpengaruh karena nilai rata-rata kualitas air pada lokasi penelitian dianggap cukup baik.

\section{PENUTUP}

Berdasarkan hasil dan pembahasan maka kesimpulan adalah sebagai berikut;

1. Ditemukan 2 jenis parasit yakni Trichodina $s p$ dan Cryptocaryon sp, dimana Ektoparasit yang ditemukan selama penelitian adalah Trichodina $s p$ yakni 28 individu dengan tingkat prevalensi $70 \%$ dan intensitas serangan 2 ind/ekor dan kelimpahan 0,4.

2. Tingkat serangan parasit terhadap ikan Kerapu Tikus (Cromileptes altevalis) belumlah berbahaya bagi tubuh ikan karena nilai intensitas 1 - 2 ind/ekor berdasarkan penyebaran di tubuh ikan yakni sisik, sirip, insang dan mata.

3. Data kualitas air yang didapatkan selama penelitian pada lokasi budidaya (KJA) sangat cocok untuk proses kegiatan Budidaya ikan Kerapu Tikus (Cromileptes altevalis).

\section{DAFTAR PUSTAKA}

Afrianto, E dan E. Liviawaty, 1992. Pengendalian Hama \& Penyakit Ikan. Kanisius, Yogyakarta Anonim, 1985. Patologi Klinik Pada Ikan. Diagnosa dan Pencegahan Penyakit Ikan. Sub Balai Penelitian Budidaya Rantai Bojonegoro, Semarang. 
Anonim, 1999. Pembenihan Ikan Kerapu Tikus (Cromileptes altevalis), Departemen Pertanian Direktorat Jenderal Perikanan Balai Budidaya Laut Lampung.

Brite, M. Elyawati dan Kurniastuti, 2003. Pengenalan Penyakit Ikan Penanganan Penyakit Ikan Budidaya Laut. Balai Budidaya Laut Lampung.

Brotohadikusumo, N.A. 1997. Dampak Pembangunan Fisik Terhadap Biota Perairan PPLH UNDIP. Semarang.

Gufron, M. 2004. Penanggulangan Hama dan Penyakit. Dicetak oleh PT. Asdi Mahasatya. Jakarta.

Laboratorium Hama dan Penyakit Ikan (HPI), 2003. Balai Budidaya Laut Ambon.

Nontji, A. 1987. Laut Nusantara Penerbit Djembatan Jakarta.

Purnowawati, R. J. Dewi dan P. Hartono. 2002. Penyakit Parasit. Pengelolaan Kesehatan Ikan Budidaya Laut. Lampung.

Rumagia, S. 2001. Studi Ektoparasit pada Benih Ikan Mas (Cyprinus carpio) dari Kolam Balai Benih Ikan Abeli Sawah Kecamatan Sampara Kabupaten Kendari. Skripsi Program Studi Budidaya Perairan Jurusan Perikanan Fakultas Pertanian Universitas Haluoleo Kendari. 